and set, called Mintaka, will always rise and set within one degree of true east and true west wherever you are in the world.

Though the techniques discussed here are accurate methods of navigating at night, there are certain things one must remember prior to attempting any of these. The most important thing to keep in mind is not to panic. If you are in a group, stick together and under no circumstances should anyone be sepa- rated from the group. Limited visibility causes the forest to become much more hazardous after sunset. Bear in mind that the techniques and principles of map and compass navigation, such as map analysis that one perfects in daylight, remain the same after dark. Should you choose to attempt celestial navigation keep in mind that this is a technique that takes practice. Try it first in a safe area that you are familiar with-a park or field, a fenced wooded property. Make sure that you are familiar with the techniques of celestial navigation prior to attempting it in the forest and be honest enough with yourself to admit if you are not $100 \%$ sure of what you are doing.

Nicole Bergevin

Marketing Coordinator and FRP/ Institute Knowledge Exchange Specialist

\title{
The Great Fire of 1922(The Haileybury Fire)
}

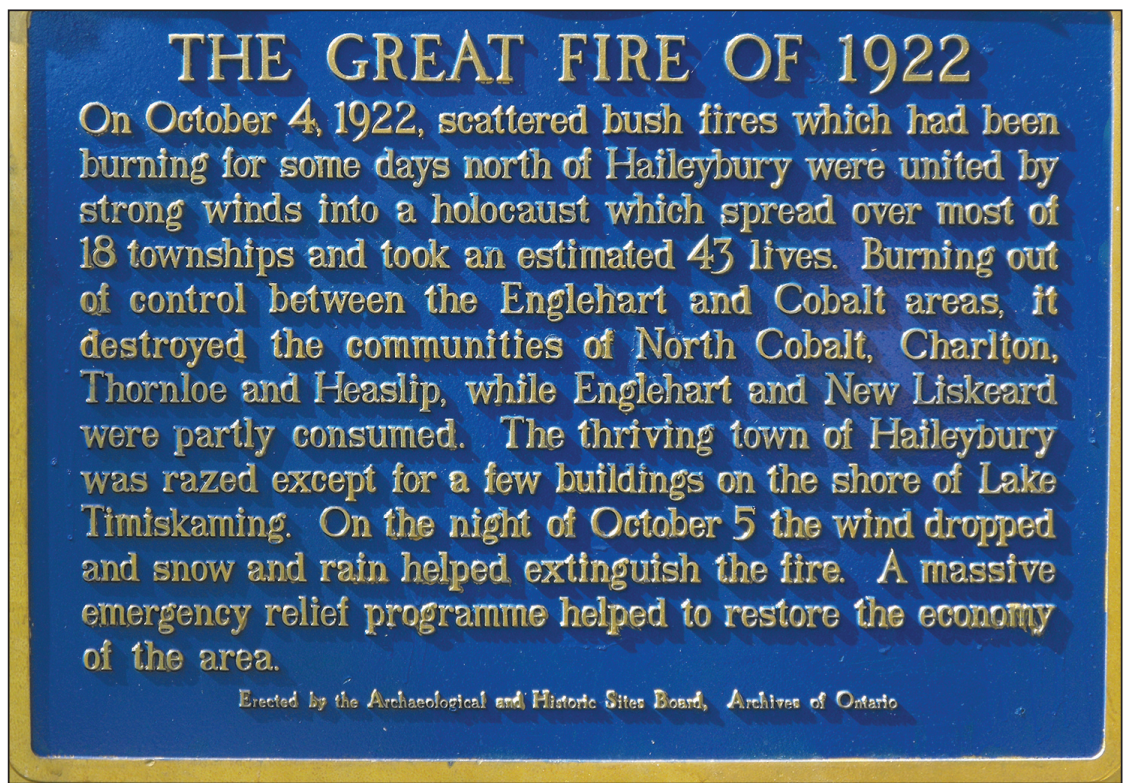

\section{Fire Report}

Place:Haileybury, Ontario;

Size of burn: over 500000 hectares; Number of people affected: 43 people killed;

Property destroyed: around $\$ 8$ million dollars' worth of damages (houses, businesses, churches and many farm animals were all destroyed);

Cause: never determined, although some believed it was arson.

The above historical fire report sums up one of Canada's 10 worst natural disasters. It was devastating to many communities. Eyewitness reports from Haileybury, Ontario and Notre-Damedu-Nord, Quebec provide an idea of the impact the fire had on people that day. Could it happen today? Have we changed enough of our knowledge and improved practices?

"The summer of 1922 was unusually hot and dry in northern Ontario, so hot and dry that worried fire rangers asked the government for permission to stay on for the approaching "burning" season, when farmers were allowed to clear land with small brush fires. Bureaucrats, however, denied the request and on September $12^{\text {th }}$, all fire rangers left the area around Lake Temiskaming. With burning permits now unnecessary, settlers were quick to take advantage and farmers began to set the small fires needed to improve their land. On October $4^{\text {th }}$, gentle fall breezes unexpectedly turned into hurricane-force winds. The small fires, burning on ground dried out from summer heat, soon merged into an inferno. In Haileybury, citizens paid little attention to the smoke, at first no different than the smoke that drifted into town every year during burning season. When the flames approached the town, however, people panicked. In the thick, black smoke, families had difficulty finding each other. A clerk at the telegraph office wired to North Bay, "Haileybury is on Fire. Send help!" Most people headed to the lake, covering themselves with wool blankets, where they waited, shivering, for six hours. By midnight the fire had finally burnt itself out, leaving 90\% of Haileybury in cinders.

\section{Source \\ Haileybury Heritage Museum}

The fire was devastating to residents. Churches that had been built as the town established itself were destroyed as was much of the town. It was definitely time to start over and re-establish the town. It is not as commonly known but 
many villages on the Quebec side were also destroyed.

The following account from Notre Dame du Nord leaves a strong realistic feel to this day:

\section{The Great Fire of 1922 - Notre-Dame-du- Nord}

"If there is an outstanding event in the collective memory of Notre-Dame-duNord citizens, it undoubtedly is the Great Fire of 1922. The fire did a lot of damage in the area at the north of Lake Timiskaming. The city of Haileybury was almost entirely destroyed, as was the city of North-Cobalt. People had to get in the water and cover themselves with wet blankets in order to save themselves from the fire."

"S'il est un événement marquant dans la mémoire collective des gens de NotreDame-du-Nord, c'est bien le Grand feu de 1922. Ce feu causa beaucoup de dégâts dans la partie nord du lac Témiscamingue. La ville de Haileybury a été presque complètement détruite, ainsi que North-Cobalt. Les gens devaient se jeter dans les eaux du lac Témiscamingue et se protéger avec une couverture mouillée pour être épargnés par le feu”.

Notre-Dame-du-Nord and NotreDame-des-Quinze communities were very affected by this fire, which happened only a few years after the Spanish flu epidemic. Every year after October 4, the Ontario provincial government used to allow people to light bush fires, even when the risk of forest fire was high due to drought. In 1922, September had been very dry and, when open fires were allowed on October 4, many fires were lit in the north. When the light wind of the morning started to turn into gusts that afternoon, the small fires became a devastating fire quickly spreading towards Haileybury and Notre-Dame-du-Nord. A witness, Hilaire Damphousse, tells the details of the fire's passage in Notre-Dame-duNord and Notre-Dame-des-Quinze :

"Distress is at a peak around 3:304:00 PM; because of the smoke, it is dark as night. But the fire doesn't stop there. It keeps ravaging towards Belle-Vallée, Notre-Dame-du-Nord and Nédelec, leaps over Des-Quinze river to propagate in Notre-Dame-des-Quinze. Like in Haileybury, wind is blowing at 80 miles an hour".
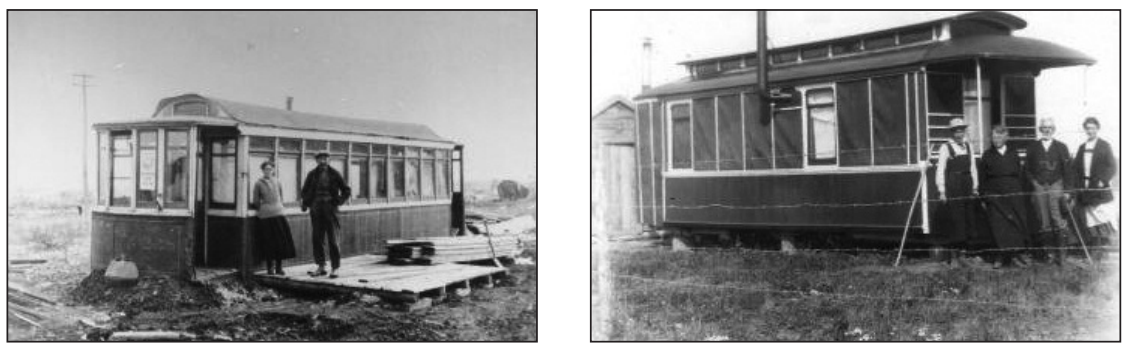

Disused Toronto streetcars were shipped north to be turned into temporary shelters.

"Here, as in Haileybury, the town is separated in half. The school burns, which had been used as a chapel since the destruction of the old Church in 1918. Today's church, as well as the presbytery, then under construction, is spared. The people whose house was not destroyed are helping as they can. Desolation is great... there are screams, moans, cries, it sad to see and hear! Around 6:00 PM, the wind turns to north-west; it saves the north part of the town, but burns the east side up to Desjardins Street. Meanwhile, because of the strong winds, the fire jumps over the river and keep ravaging in Notre-Dame-des-Quinze. The fire is everywhere (...) In the evening, around 11:00, the wind becomes very cold and, gathered around a fire (this one much kinder) to warm up, people appreciate from the bottom of their heart the blankets and food given to them. The Great Fire has left desolation everywhere. The morning after, eyes aching and red, the people look, desperate, the six inches of snow, darkened by the ashes, that fell overnight and that is covering the carcasses of the cattle and the remains of the houses. Desperate to the last point, no one can say a word without letting tears drop. It's back to square one."

Source

Hilaire DAMPHOUSSE, Le Grand Feu de 1922, Manuscrit sans date et Livre du Centenaire: Notre-Dame-du-Nord, 1896-1996
Haileybury Heritage Museum had a celebration of the $90^{\text {th }}$ anniversary of the fire on September 29 and $30^{\text {th }}$.Seven survivors of the 1922 fire attended the celebration. "Bogart Leslie, age 102, played an active role in the celebration" said Allan Bellaire, museum curator. Having had many large fires near Kirkland Lake and Timmins in 2012 brought the memories back for many families of the great fires of Haileybury 1922 and the Porcupine Fire of 1911. It also makes us think how much damage the fires of 2012 might have caused if we did not have the water bombers, helicopters, fire crews and an intensive Fire Management Program in Ontario. We still had a fire that consumed 50000 hectares and lost property but no loss of life. We have learned much but still need to keep continuously learning and improving.

Rob Galloway, RPF Director, Forest History Society of Ontario 
FOREST SECTOR INNOVATION: SEIZING OPPORTUNITIES TO CREATE VALUE INNOVATION DU SECTEUR FORESTIER :
SAISIR LES OPPORTUNITESS POUR CRÉER DE LA VALEUR

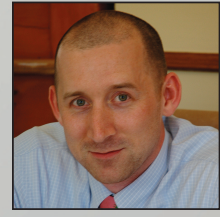

Forest Sector Innovation: a priority

for the Canadian Forest Service

Glenn Hargrove

Director, CFS

December 12, 2012

Cross-laminated timber: A New

Generation of Engineered Wood Product

Mohammad Mohammad

Research Leader - Serviceability \& Fire,

FPInnovations

December 19, 2012

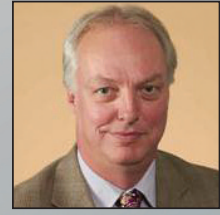

The Canadian Innovation System - aligned for a competitive forest sector

George Bruemmer

Executive Director, CWFC

January 9, 2013

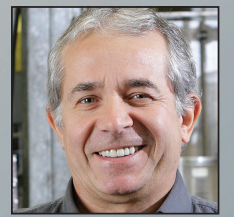

Black Gold : Pyrolytic Conversion of Biomass Residues into Bio-Oil and Bio-Char

Dr. Franco Berruti

Professor of Chemical Engineering Western University, London, Ontario

January 16, 2013

Capitalizing on opportunities created by increasing demand for sustainability

Xuejun Zou

Research Manager, Paper, Packaging and

Consumer Products, FPInnovations

January 23, 2013

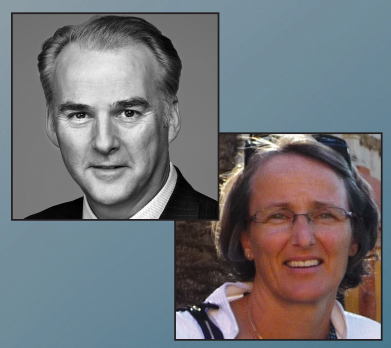

The power to accelerate innovation strengthening connections among academic research networks

Jean-Pierre Martel, Vice President, Strategic Partnerships, FPInnovations Paule Têtu, University Strategic Partnerships Advisor, FPInnovations January 30, 2013
All electronic lectures are free. Your consideration of CIF/IFC membership would be appreciated.

www.cif-ifc.org/site/electure

To become a CIF/IFC member: www.cif-ifc.org/site/join

11:30 a.m. MST; 1:30 p.m. EST FOR ADDITIONAL INFORMATION

OR TO REGISTER, CONTACT:

Dan Marina

Canadian Institute of Forestry/

Forestry Research Partnership

E-mail: dmarina@cif-ifc.org or

Tel: 705-744-1715 ext. 630 Fax: 705-744-1716 